Damjana Panić ${ }^{1}$

University of Niš

Faculty of Philosophy

Department of Psychology

Niš, Serbia

\section{Milkica Nešić}

University of Niš

Faculty of Medicine

Niš, Serbia

\section{Marina Hadži Pešić}

University of Niš

Faculty of Philosophy

Department of Psychology

Niš, Serbia
UDK 159.942:159.923.3; 159.925

Original scientific paper

DOI: https://doi.org/10.46630/gpsi.18.2019.01

\title{
NEGATIVE EMOTIONS AND PSYCHOSOMATIC MANIFESTATIONS: COMMON FEATURES AND DIFFERENCES BETWEEN THE TYPE A BEHAVIOR PATTERN AND TYPE D PERSONALITY ${ }^{2}$
}

\begin{abstract}
The Type A Behavior Pattern (TABP) and Type D personality (Type D) are constructs primarily related to cardiac patients as they may contribute to the onset, course, and outcome of cardiovascular diseases, but their association with other adverse health outcomes is also noticeable. The aim of this study was to examine the interrelationship between TABP and Type D, as well as their predictive role for general proneness to psychosomatic manifestations. A cross-sectional, correlational study was conducted among 212 healthy volunteers. The correlation analyses showed that there was an association between Impatience-Irritability and Negative affectivity $\left(r=.191^{* *}\right)$ as components of TABP and Type D, respectively. Furthermore, it was found that both TABP and Type D have a significant percentage of the cumulative variance in the proneness to psychosomatic manifestations, with Type D proving to be a stronger predictor than TABP. Impatience-Irritability $\left(\beta=.17^{* *}\right)$, Negative affectivity $(\beta=$ $\left..56^{* * *}\right)$, and Social inhibition $\left(\beta=.17^{* *}\right)$ were distinguished as significant predictors for suggesting an association between negative emotions as components of these constructs and psychosomatic manifestations.
\end{abstract}

Keywords: Negative emotions, Psychosomatics, Type A Behavior Pattern, Type D personality

\footnotetext{
${ }^{1}$ Corresponding author email: damjana.panic@filfak.ni.ac.rs

${ }^{2}$ This research was supported by a Faculty of Philosophy internal project "Applied psychology as a function of an individual's life quality in the community", No. 183/1-16-9-01
} 


\section{Introduction}

A well-known fact since ancient times is that emotional factors can play an important role in physical health, that is, in the functional and structural disorders of particular organs and systems (Salovey, Rothman, Detweiler, \& Steward, 2000). Today, the term psychosomatic diseases is widely accepted to describe physical symptoms that are not linked to any specific physiological dysfunction or explained by a specific medical condition (Gupta \& Pérez-Edgar, 2012; Humaida, 2012), in order to emphasize the link between the cumulative effects of negative emotions, subjective distress, and numerous somatic complaints and disorders as an example of the inseparability of psyche and body.

Over the last few decades, a large number of studies investigating emotions, either separately or as components of certain behavioral syndromes and/or personality constructs, have examined the association between negative affect and psychosomatic disorders.

During the second half of the 20th century, a number of physicians, and later researchers, paid particular attention to the Type A Behavior Pattern (TABP), an action-emotional complex which was discovered to be associated with various somatic diseases, primarily coronary heart disease (CHD). This behavioral style was described by cardiologists Friedman and Rosenman (1974), and is characterized by a high level of ambitiousness, competitiveness, continuous striving for achievement over a short period of time with a constant feeling of time urgency, as well as impatience, irritability, and hostility towards others. TABP can be associated with greater achievements and success (e.g., De la Fuente \& Cardelle-Elawar, 2009; Matthews, Helmreich, Beane, \& Lucker, 1980), but it is almost equally, if not more often, associated with patients suffering from CHD (e.g., Friedman \& BoothKewley, 1987; Gallacher, Sweetnam, Yarnell, Elwood, \& Stansfeld, 2003) or other health issues, psychosomatic symptoms and disorders (Pickering, 2009; Spector \& O'Connell, 1994). However, although many studies conducted during the past decades have revealed an association between TABP and CHD, there have also been some contrary data (e.g., Ben-Zur, 2002; Ravaja, Keltikangas-Jarvinen, \& Keskivaara, 1996; Schulman \& Stromberg, 2007). Thus, there is relative agreement that various components involved in this complex participate differently in the development of CHD and other (psycho)somatic diseases. It is noticeable that aggressiveness/ hostility is actually a "pathogenic core" of this behavior style (Rosenman, 1991). The majority of studies (e.g., Gallo \& Matthews, 2003; Rutledge \& Hogan, 2002), including meta-analytic reviews (Myrtek, 2001), have established that hostile people are at increased risk of subsequent CHD or other diseases, and they have emphasized hostility as a risk factor for a number of negative health outcomes independently of its associations with other Type A components.

At the end of the 20th century, a new personality construct, the Type D or "distressed" personality, was introduced (Denollet, 2000). Type D represents an interaction between two stable features - Negative affectivity (NA) and Social 
Inhibition (SI) (Denollet, 1998). NA is a tendency to experience negative emotions such as anxiety, depressiveness, guilt and anger, while SI refers to the suppression of these feelings in interpersonal relations, mainly due to the fear of rejection, as well as tenseness and insecurity in social interactions. Persons with Type D characteristics can be described as gloomy, anxious, worried, and inept in social relations. It is important to note that Type D is a common personality construct which does not refer to psychopathology (Denollet, 2005). Its prevalence varies between $13 \%$ and $25 \%$ in the general population and between $26 \%$ and $53 \%$ in cardiac patients (e.g., Aquarius, Denollet, Hamming, \& De Vries, 2005; Denollet, 2005), and it can be considered a vulnerability factor for general psychological distress, affecting mental as well as physical health. Recent studies suggest that Type D can be linked with mechanisms contributing to CHD, myocardial infarction, and sudden cardiac death (e.g., Denollet, 2005; Denollet, Pedersen, Vrints, \& Conraads, 2006), but also to a lower quality of life and lower psychological functioning among diabetic and cancer patients (Mols, Thong, Van de Poll-Franse, Roukema, \& Denollet, 2012; Nefs, Pouwer, Denollet, \& Pop, 2012) and patients with metabolic syndrome (Mommersteeg, Kupper, \& Denollet., 2010), as well as lower health status in the general population (e.g., Jellesma, 2008; Williams \& Wingate, 2012). Migraine headaches have long been associated with stress and negative emotions. Furthermore, individuals who control their emotional expression and inhibit their feelings could be prone to rheumatoid arthritis. It is assumed that their negative emotional states alternate with the somatization of tension that is manifested in muscle inhibition and arthritis, thus disturbing both movement and active emotional expression (Nešić, Nešić, \& Hadži Pešić, 2013).

To sum up, an overview of the available data suggests the important role of both TABP and Type D in regard to CHD and other (psycho)somatic diseases. It seems that people who have chronic experience of one or more negative emotions such as depressiveness, anxiety, anger, aggressive or competitiveness seem to have a greater risk of CHD (Friedman \& Booth-Kewley, 1987), as do those who report emotional suppression and social inhibition and feeling rejected and defeated (Gračanin, 2005; Schmidt-Pedersen \& Middel, 2001). An overview of the available data also indicates that only a few studies have assessed the role of TABP and Type D in relation to the general proneness to psychosomatic manifestations in apparently healthy people. Having in mind that both concepts refer to normal and not to psychopathological features, it seems reasonable to examine their potential significance in terms of proneness to psychosomatics in the general population. Furthermore, to our knowledge, very few studies have simultaneously investigated and compared these variables, which explains the existence of inconsistent findings (Suls \& Bunde, 2005). There are certain data indicating an association between TABP and the presence of negative emotions (Byrne \& Reinhart, 1990; Mellam \& Espnes, 2003), as well as findings suggesting that Type D people are more hostile, cynical and even physically aggressive, i.e., they experience anger towards themselves or others more frequently (Perbandt, Hodapp, Wendt, \& Jordan, 2006). However, there are not many such studies. Taking into account that researchers rarely address the connection between 
TABP and Type D simultaneously, or their potential contribution to proneness to psychosomatics in general, the aims of this study were to investigate whether these constructs are related to each other and if they have a significant predictive role in the proneness to psychosomatic manifestations.

\section{Method}

\section{Sample and procedure}

A cross-sectional, correlational study was conducted on a sample that consisted of 212 participants aged between 19 and 62 years. The mean age of the participants was $27.69 \pm 9.59$. Fifty four of them $(25.5 \%)$ were male, with a mean age of $29.29 \pm 9.91$ and $154(74.5 \%)$ were female, with a mean age of $27.15 \pm 9.45$ ( $p=$ .160). Participation in the research was anonymous and voluntary. All participants were briefly introduced to the research goals and given instructions on filling out the questionnaires.

\section{Measures}

The Jenkins's Activity Scale for Type A (Pred, Spence, \& Helmreich, 1986). The scale was adapted to consist of 12 items rated on a 5-point Likert scale that assess two components of this behavior style. Achievement Strivings (AS), with 7 items, refers to hard driving, activity, and achievement related behaviors (e.g. "How seriously do you take your work?"), while Impatience-Irritability (II), with 5 items, relates to intolerance, anger, hostility, and a preoccupation with a lack of time (e.g. "Do you tend to do things in a hurry?"). The scale's reliability is presented in Table 1.

Type D personality was assessed with the the Type-D Scale-14 (DS-14; Denollet, 2005). The scale consists of 14 items and comprises two subscales with 7 items each for NA and SI. NA relates to the stable tendency to experience negative emotions (e.g. "I often feel unhappy"), and SI refers to inhibitions in expressing these feelings in interpersonal relations (e.g. "I would rather keep other people at a distance"). Answers are rated on a 5-point Likert scale. The reliability data are presented in Table 1.

The Hi test for measuring proneness to psychosomatics is part of the Conative Test Battery (KON 6; Momirović, Wolf i Džamonja, 1992). It is a selfreport measure with 30 items (e.g. "I feel dizziness and nausea after hard endeavors") which are rated on a five-point Likert scale. Somatic complaints are primarily related to cardiovascular, respiratory, gastrointestinal, and urogenital systems, but also to sensory and motor, as well as to hypochondric reactions toward the mentioned complaints. The scale's reliability, assessed using Cronbach's $\alpha$, was .910 .

\section{Statistical Analysis}

Descriptive statistics for TABP and Type D were given in terms of means and standard deviations, and the reliability of the scales was assessed using Cronbach's 
$\alpha$. In order to investigate the association between the variables, Pearson correlations were calculated. Hierarchical regression analysis was used to examine whether TABP and Type D were significant predictors of proneness to psychosomatic manifestation.

\section{Results}

The results showed a weak positive correlation between II as a characteristic of TABP and NA as a component of the Type D personality, while no other correlations for Type A or Type D characteristics were established. There was a weak positive correlation between AS and II as components of TABP and a moderate positive correlation between NA and SI as characteristics of a Type D personality. The internal consistency reliability of both Type D scales was good, but it was not satisfactory for the TABP scales (Table 1). The reliability of the HI test was also assessed using Cronbach's $\alpha$, and it was good, $\alpha=.910$.

Table 1

Intercorrelations between TABP and Type D personality, descriptive statistics, and reliability of the scales

\begin{tabular}{|c|c|c|c|c|c|c|c|}
\hline \multirow{2}{*}{\multicolumn{2}{|c|}{ Variables }} & \multicolumn{3}{|c|}{$r$} & \multirow[t]{2}{*}{$M$} & \multirow[t]{2}{*}{$S D$} & \multirow[t]{2}{*}{$\alpha$} \\
\hline & & II & NA & SI & & & \\
\hline \multirow{2}{*}{ 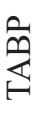 } & AS & $.155^{*}$ & .032 & -.048 & 24.94 & 4.25 & .637 \\
\hline & II & & $.191^{* *}$ & -.015 & 16.91 & 3.16 & .406 \\
\hline \multirow{2}{*}{ 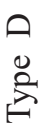 } & NA & & & $.473^{* *}$ & 10.82 & 6.72 & .883 \\
\hline & SI & & & & 9.12 & 6.05 & .842 \\
\hline
\end{tabular}

Note. AS = Achievement Strivings; II = Impatience-Irritability; NA = Negative Affectivity; SI = Social Inhibition.

$* * p<.01 ; * * * p<.001$.

Hierarchical regression analyses were conducted in order to examine the predictive role of the characteristics of Type A and Type D for their proneness to psychosomatic manifestations. In the first step, the TABP components AS and II were included, while in the second step, Type D personality characteristics were used as predictors of proneness to psychosomatic manifestations. The result in the first step shows that TABP components accounted for $8 \%$ of the variance in the proneness to psychosomatic manifestations, with only II being a significant predictor $(b=1.56, S E=.37, \beta=.28 * *)$. The Type D Personality characteristics added in the second step accounted for an additional $42.5 \%$ of the variance in the proneness to psychosomatic manifestations. NA $\left(b=1.47, S E=.15, \beta=.56^{* * *}\right)$ and SI $(b=.49$, $\left.S E=.16, \beta=.17^{* * *}\right)$, as well as II $\left(b=.97, S E=.28, \beta=.17^{* *}\right)$ from the previous 
step were singled out as significant predictors. All predictors had a positive partial contribution and overall, the study variables accounted for $50.2 \%$ of the variance in the proneness to psychosomatic manifestations (Table 2).

Table 2

Hierarchical regression of proneness to psychosomatic manifestations on TABP and Type D personality characteristics

\begin{tabular}{|c|c|c|c|c|c|c|c|c|}
\hline \multirow[t]{2}{*}{ Predictors } & \multicolumn{5}{|c|}{ Step 1} & \multicolumn{3}{|c|}{ Step 2} \\
\hline & $b$ & $\begin{array}{l}95 \% \mathrm{CI} \\
\text { for } b\end{array}$ & $S E$ & $\beta$ & $b$ & $\begin{array}{l}95 \% \mathrm{CI} \\
\text { for } b\end{array}$ & $S E$ & $\beta$ \\
\hline AS & -.27 & {$[-.86, .28]$} & .28 & -.06 & -.24 & {$[-.64, .17]$} & .21 & -.06 \\
\hline II & 1.56 & {$[.82,2.29]$} & .37 & $.28 * * *$ & .97 & {$[.41,1.53]$} & .28 & $.17 * *$ \\
\hline NA & & & & & 1.47 & {$[1.18,1.77]$} & .15 & $.56^{* * *}$ \\
\hline SI & & & & & .49 & {$[.17, .81]$} & .16 & $.17 * *$ \\
\hline $\begin{array}{l}\text { Model } \\
\text { Summary }\end{array}$ & \multicolumn{4}{|c|}{$\begin{array}{c}R=.23, R^{2}=.08, \Delta R^{2}=.08 \\
F(2,209)=8.71^{* * *}\end{array}$} & \multicolumn{4}{|c|}{$\begin{array}{l}R=.71, \mathrm{R}^{2}=.50, \Delta R^{2}=.42 \\
07)=52.16^{* * *}, F_{\text {change }}=88.34 * * *\end{array}$} \\
\hline
\end{tabular}

Note. $\mathrm{AS}=$ Achievement Strivings: $\mathrm{II}=$ Impatience-Irritability; NA = Negative

Affectivity; SI - Social Inhibition. All values are rounded to two digits.

$* * p<.01 ; * * * p<.001$.

\section{Discussion}

The role of emotional factors in the functional and structural disorders of particular organs and systems has been widely discussed (Salovey et al., 2000). Numerous studies that have investigated the association of TABP and Type D with negative health outcomes suggest that negative emotions, as a part of either of these constructs, as well as their suppression, are the highest risk factors for a variety of negative health outcomes (Denollet, 2000; Gallo \& Matthews, 2003). However, researchers rarely address the connection between TABP and Type D simultaneously, or their potential contribution to the proneness to psychosomatics in general, hence the aim of this study was to examine the intercorrelations between the components of TABP and Type D, as well as their predictive role in the general proneness to psychosomatic manifestations.

The correlation analyses indicate a positive correlation between II as a component of TABP and NA as a characteristic of Type D. These findings can only be partly compared with the previous evidence showing an association between TABP and the experience of negative emotions (Byrne \& Reinhart, 1990; Mellam \& Espnes, 2003), as well as an association between Type D personality and hostility (Perbandt et al., 2006), since the present research exclusively examines the intercorrelations between the components of TABP and Type D, and not those in general, as was the 
case in the studies mentioned. It is also important to note that the correlation found was weak, and no other correlations between the components of TABP and Type D were observed, which suggested their independence. A weak positive correlation was also revealed between AS and II as TABP components, thereby suggesting that they were relatively independent characteristics of this behavior style (Spence, Helmreich, $\&$ Pred, 1987). On the other hand, there was a moderate positive correlation between NA and SI as Type D characteristics, which was also consistent with Type D being defined as a combination of two stable traits - NA and SI (Denollet, 1998).

The results also indicate a predictive role of both TABP and Type D for proneness to psychosomatic manifestations, but their contribution to the cumulative percentage of the explained variance of proneness to psychosomatics is different - Type D proved to be a stronger predictor than TABP. Namely, TABP components accounted for $8 \%$ of the variance in the proneness to psychosomatic manifestations, while an additional $42.5 \%$ of variance was explained by including Type D characteristics as predictors. Both Type D characteristics and II as a component of TABP were distinguished as significant predictors, while AS as a component of TABP did not have a significant predictive role. The results are in line with previous studies examining Type D in the general population, which established its association with poor health status and the frequent presence of various somatic symptoms (Jellesma, 2008; Mols \& Denollet, 2010). In addition, the previous findings suggest that Type D is more prevalent in psychosomatic patients (Grande et al., 2004). The findings obtained are also consistent with the previous ones that II as a part of TABP, but not AS is associated with more frequent reports of negative health symptoms (Kivimaki, Kalimo, \& Julkunen, 1996; Spence et al., 1987), suggesting thereby that ambitiousness itself may not necessarily be negatively related with a lower health status, and that the above mentioned components of TABP can be perceived separately, which is supported by previous findings (Spence et al., 1987), as well as by the correlation analysis results in this research.

There have been many attempts to explain potential mechanisms linking TABP and Type D characteristics with CHD, but there is still a lack of precise data to show how these characteristics are linked with psychosomatic manifestations in general (Leventhal, Musumeci, \& Leventhal, 2006).

The data available suggest the role of health behaviors in the development of negative health outcomes. The unhealthy life habits of hostile people (e.g., smoking, a lower level of physical activity) (Siegler, 1994) may be relevant for the association between hostility and negative health outcomes. Type D individuals are also more prone to health compromising behaviors, such as poor nutrition, smoking and irregular medical check-ups, than their non-Type D counterparts (Williams et al., 2008). However, previous findings indicate the partial mediating effect of health behaviors in the relationship between Type D and physical symptoms (Williams, Abbott, \& Kerr, 2015), thus suggesting the relevance of other factors in explaining its relationship with negative health outcomes, such as social support and coping (Williams \& Wingate, 2012).

One possible explanation should be through the communication of emotional states. Type D individuals, besides being prone to experiencing negative affectivity, 
also inhibit their feelings in social situations, and lose the possibility of affecting their environment. Numerous studies also emphasize that irritable and hostile people usually report lower levels of social support (McCann, Russo, \& Benjamin, 1997) and often come into interpersonal conflicts and react strongly to them.

There are also some hypotheses regarding potential psychophysiological mechanisms linking Type D and TABP with physical symptoms. However, in most biologically-based personality theories, affects and behavioral systems are sometimes closely linked with particular physiological structures and transmitters, but sometimes the connection is merely superficial (Nešić \& Nešić, 2011), which increases the risk of assessment of association between psychosocial and health variables.

To summarize, it seems that although TABP and Type D personality refer to separate constructs, the mechanisms associating them with poor health status can be very similar. The current research findings reaffirm previous data that numerous health-related traits primarily refer to negative emotions, either as a part of TABP or Type D personality (Matthews \& Deary, 2003; Todaro, Shen, Niaura, Spiro, \& Ward, 2003). It emerges that exaggerated experience of negative emotions, as well as their suppression may be the background for the onset of psychosomatic manifestations. Since the present findings revealed Type D as more harmful, the potential benefits of Impatience-Irritability, i.e., anger itself, should be taken into account, because although it can be potentially dangerous, it is less dangerous than some of the other characteristics related to Type D. However, it should be taken into account that the risk assessment for psychosomatic diseases based on personality characteristics and other psychosocial variables is very complicated, due to the complexity of measuring personality structure and physiological distress and their relationship with individual health status, as well as due to the lack of a universal methodology (Jovanović, Jakovljević, Paunović, \& Grubor, 2006). Since the last of the above mentioned causes is consistent with the cross-sectional design of the present study, it has limited the possibility of testing the causal hypotheses. Further research, primarily longitudinally designed, is required to investigate the mechanisms which possibly relate negative emotions and psychosomatic manifestations in more detail. As for the limitations of this research it should be noted that self-reported measures were administered. In addition, since neither of the two TABP scales has demonstrated satisfactory reliability, the research findings should be accepted with caution and need replication/verification in further research.

\section{References}

Aquarius, A. E., Denollet, J., Hamming, J. F., \& De Vries, J. (2005). Role of disease status and Type D personality in outcomes in patients with peripheral arterial disease. American Journal of Cardiology, 96(7), 996-1001.

Ben-Zur, H. (2002). Associations of Type A behavior with the emotional traits of anger and curiosity. Anxiety, Stress, and Coping: An International Journal, 15(1), 95-104. 
Byrne, D. G., \& Reinhart, M. I. (1990). Self-reported distress, job satisfaction and the Type A behaviour pattern in a sample of full-time employed Australians. Work \& Stress, 4(2), 155-166.

De la Fuente, J., \& Cardelle-Elawar, M. (2009). Research on action-emotion style and study habits: Effects of individual differences on learning and academic performance of undergraduate students. Learning and Individual Differences, 19(4), 567-576.

Denollet, J. (1998). Personality and coronary heart disease: The Type-D Scale-16 (DS16). Annals of Behavioral Medicine, 20(3), 209-215.

Denollet, J. (2000). Type D personality. A potential risk factor defined. Journal of Psychosomatic Research, 49(4), 255-266.

Denollet, J. (2005). DS14: Standard assessment of negative affectivity, social inhibition, and Type D personality. Psychosomatic Medicine, 67(1), 89-97.

Denollet, J., Pedersen, S. S., Vrints, C. J., \& Conraads, V. (2006). Usefulness of type-D personality in predicting five-year cardiac events above and beyond concurrent symptoms of stress in patients with coronary heart disease. American Journal of Cardiology, 97(7), 970-973.

Friedman, M., \& Rosenman, R. (1974) Type A Behavior and Your Heart. New York: Knopf.

Friedman, H. S., \& Booth-Kewley, S. (1987). Personality, type A behavior, and coronary heart disease: the role of emotional expression. Journal of Personality and Social Psychology, 53(4), 783-792.

Gallo, L. C., \& Matthews, K. A. (2003). Understanding the association between socioeconomic status and physical health: Do negative emotions play a role? Psychological Bulletin, 129(1), 10-51.

Gallacher, J. E. J, Sweetnam, P. M, Yarnell, J. W. G., Elwood, P.C., \& Stansfeld, S. A. (2003). Is Type A behavior really a trigger for coronary heart disease events? Psychosomatic Medicine 65(3), 339-346.

Gračanin, A. (2005). Afektivne, kognitivne, socijalne i zdravstvene posljedice emocionalne supresije [Affective, cognitive, social, and health consequences of emotional suppression] . Psihologijske teme, 14(1), 91-107

Grande, G., Jordan, J., Kummel, M., Struwe, C., Schubmann, R. et al. (2004). Evaluation of the German Type D Scale (DS14) and prevalence of the Type D personality pattern in cardiological and psychosomatic patients and healthy subjects. Psychotherapie, Psychosomatik und Medizinische Psychologie, 54(11), 413-422.

Gupta, D., \& Pérez-Edgarn, K (2012). The role of temperament in somatic complaints among young female adults. Journal of Health Psychology, 17(1), 26-35.

Humaida, I. A. I. (2012). Relationship between stress and psychosomatic complaints among nurses in Tabarjal Hospital. Open Journal of Medical Psychology, 1(03), 15-19.

Jellesma, F. C. (2008). Health in Young People: Social Inhibition and Negative Affect and Their Relationship with Self-Reported Somatic Complaints. Journal of Developmental \& Behavioral Pediatrics, 29(2), 94-100.

Jovanović, D., Jakovljević, B., Paunović, K. i Grubor, D. (2006). Značaj osobina ličnosti i psihosocijalnih faktora za razvoj koronarne bolesti srca [The importance of personality features and psychosocial factors in the development of coronary heart disease]. Vojnosanitetski pregled, 63(2), 153-158. 
Kivimaki, M., Kalimo, R., \& Julkunen, J. (1996). Components of Type A behavior pattern and occupational stressor-strain relationship: Testing different models in a sample of industrial managers, Behavioral Medicine 22(2), 67-76.

Leventhal, H., Musumeci, T. J., \& Leventhal, E. A. (2006). Psychological approaches to the connection of health and behaviour. South African Journal of Psychology, 36(4), 666-682.

Matthews, K. A., Helmreich, R. L., Beane, W. E., \& Lucker, G. W. (1980). Pattern A, achievement striving, and scientific merit: Does pattern a help or hinder? Journal of Personality and Social Psychology, 39(5), 962-967.

Matthews, G., \& Deary, I. J. (2003). Personality traits 2nd ed. Cambridge: Cambridge University Press.

McCann, B. S., Russo, J., \& Benjamin, G. A. (1997). Hostility, social support, and perceptions of work. Journal of Occupational Health Psychology, 2(2), 175-185.

Mellam, A. C., \& Espnes, G. A. (2003). Emotional distress and the type A behaviour pattern in a sample of civil servants. Personality and Individual Differences, 34(7), 1319-1325.

Mols, F., \& Denollet, J. (2010). Type D personality in the general population: a systematic review of health status, mechanisms of disease, and work-related problems. Health Quality Life Outcomes, 8(9), 1-10.

Mols, F., Thong, M. S., Van de Poll-Franse, L. V., Roukema, J. A., \& Denollet, J. (2012). Type D (distressed) personality is associated with poor quality of life and mental health among 3080 cancer survivors. Journal of Affective Disorders, 136(1-2), 26-34.

Mommersteeg, P. M., Kupper, N., \& Denollet. J. (2010). Type D personality is associated with increased metabolic syndrome prevalence and an unhealthy lifestyle in a crosssectional Dutch community sample. BMC Public Health, 10(1), 714.

Momirović, K., Wolf, A. i Džamonja, Z. (1992). KON 6: Kibernetička baterija konativnih testova [KON 6: Cybernetic battery of conative tests]. Beograd: Centar za primenjenu psihologiju.

Myrtek, M. (2001). Meta-analyses of prospective studies on coronary heart disease, type A personality, and hostility. International Journal of Cardiology, 79(2-3), 245-251.

Nefs, G., Pouwer, F., Denollet, J., \& Pop, V. (2012). The course of depressive symptoms in primary care patients with type 2 diabetes: results from the Diabetes, Depression, Type D Personality Zuidoost-Brabant (DiaDDZoB) study. Diabetologia, 55(3), 608-616.

Nešić, M. i Nešić, V. (2011). Biosocijalni modeli ličnosti. U V. Nešić, A. Kostić i V. Hedrih (Ur.), Ličnosti i socijalne situacije (str. 9-33). Niš: Filozofski fakultet.

Nešić, M., Nešić, V. i Hadži Pešić, M. (2013). Stres i hronične somatske bolesti. U V. Hedrih, J. Todorović i M. Ristić (Ur.), Odnosi na poslu i u porodicu u Srbiji početkom XXI veka (str. 131-163). Niš: Filozofski fakultet.

Perbandt, K., Hodapp, V., Wendt T., \& Jordan, J. (2006). The distressed personality (Type D) - correlations with anger, aggression and hostility. Psychotherapie, Psychosomatik, Medizinische Psychologie, 56(8), 310-317.

Pickering, D. I. (2009). The role of perceived social support and stress in the Type A cognition-symptom relationship. Journal of Rational-Emotive \& Cognitive-Behavior Therapy, 27(1), 1-22. 
Pred, R. S., Spence, J. T., \& Helmreich, R. L. (1986). The development of new scales for the Jenkins Activity Survey Measure of the Type A construct. Social \& Behavioral Sciences Documents 16(2), Manuscript No. 2769. (Published from 1971 to 1985 by the APA as Catalog of Selected Documents in Psychology).

Ravaja, N., Keltikangas-Jarvinen, L., \& Keskivaara, P. (1996). Type A factors as predictors of changes in the metabolic syndrome precursors in adolescents and young adults: A 3-year follow-up study. Health Psychology, 15(1), 18-29.

Rosenman, R. H. (1991). Type A behavior pattern: A personal overview. In M. J. Strube (Ed.), Type A behavior (pp. 1-24). Newbury Park, CA: Sage.

Rutledge, T., \& Hogan, B. E. (2002). A quantitative review of prospective evidence linking psychological factors with hypertension development. Psychosomatic Medicine, 64(5), 758-766.

Salovey, P., Rothman, A. J., Detweiler, J. B., \& Steward, W. T. (2000). Emotional states and physical health. American psychologist, 55(1), 110-121.

Schulman, J. K., \& Stromberg, S. (2007). On the value of doing nothing: anger and cardiovascular disease in clinical practice. Cardiology in Review, 15(3), 123-132.

Siegler, I. C. (1994). Hostility and risk: Demographic and lifestyle variables. In A. W. Siegman, \& T. W. Smith (Eds.), Anger, hostility, and the heart (pp. 199-214). Hillsdale, NJ: Lawrence Erlbaum,.

Schmidt-Pedersen, S., \& Middel, B. (2001) Increased vital exhaustion among type-D patients with ischemic heart disease. Journal of Psychosomatic Research, 51, 443449.

Spence, J. T., Helmreich, R. L., \& Pred, R. S. (1987). Impatience versus achievement strivings in the type A pattern: Differential effects on students' health and academic achievement. Journal of Applied Psychology, 72(4), 522-528.

Spector, P. E. \& O'Connell, B. J. (1994). The contribution of personality traits, negative affectivity, locus of control and type A to the subsequent reports of job stressors and job strains. Journal of Occupational and Organizational Psychology, 67(1), 1-12.

Suls, J., \& Bunde, J. (2005). Anger, anxiety, and depression as risk factors for cardiovascular disease: the problems and implications of overlapping affective dispositions. Psychological Bulletin, 131(2), 260-300.

Todaro, J. F., Shen, B. J., Niaura, R., Spiro, A., \& Ward, K. D. (2003). Effect of negative emotions on frequency of coronary heart disease (The Normative Aging Study). American Journal of Cardiology, 92(8), 901-906.

Williams, L., O’Connor, R. C., Howard, S., Hughes, B. M., Johnston, D. W. et al. (2008). Type-D personality mechanisms of effect: The role of health-related behavior and social support. Journal of Psychosomatic Research, 64(1), 63- 69.

Williams, L., \& Wingate, A. (2012). Type D personality, physical symptoms and subjective stress: The mediating effects of coping and social support. Psychology \& health, 27(9), 1075-1085.

Williams. L., Abbott, C., \& Kerr, R. (2016). Health behaviour mediates the relationship between Type D personality and subjective health in the general population. Journal of Health Psychology, 21(10), 2148-2155. 


\title{
Damjana Panić ${ }^{3}$
}

Univerzitet $u$ Nišu

Filozofski fakultet

Departman za psihologiju

Niš, Srbija

\section{Milkica Nešić}

Univerzitet $u$ Nišu

Medicinski fakultet

Niš, Srbija

\section{Marina Hadži Pešić \\ Univerzitet $u$ Nišu \\ Filozofski fakultet \\ Departman za psihologiju \\ Niš, Srbija}

\section{NEGATIVNE EMOCIJE I PSIHOSOMATSKE MANIFESTACIJE: SLIČNOSTI I RAZLIKE A TIPA PONAŠANJA I D TIPA LIČNOSTI}

\begin{abstract}
Apstrakt
A tip ponašanja i D tip ličnosti predstavljaju konstrukte koji se prevashodno povezuju sa kardiološkim pacijentima, odnosno koji mogu biti jedan od faktora koji doprinose nastanku, ali i toku i oporavku pacijenta koji boluju od koronarne bolesti. U ovom istraživanju nastojali smo da ispitamo međusobni odnos ovih konstrukata, tj. karaktersika koje ih čine, kao i njihovu prediktivnu ulogu za uopštenu sklonost ka psihosomatskim ispoljavanjima kod zdravih ispitanika. Istraživanje je sprovedeno na prigodnom uzorku od 212 ispitanika oba pola. Rezultati ukazuju da postoji povezanost između Nestrpljivosti-razdražljivosti u okviru A tipa ponašanja i Negativne afektivnosti kao komponente D tipa ličnosti $\left(r=.191^{* *}\right)$. Utvrđeno je da i A tip ponašanja i D tip ličnosti imaju značajan udeo u varijansi psihosomatskih ispoljavanja, ali da je procenat varijanse koji se može objasniti D tipom ličnosti veći. Kao značajni prediktori sklonosti ka psihosomatskim ispoljavanjima su se izdvojili Nestrpljivost-razdražljivost $(\beta$ $\left.=.17^{* *}\right)$, Negativna afektivnost $\left(\beta=.56^{* * *}\right)$ i Socijalna inhibicija $(\beta=.17 * *)$, odnosno karakterstike koje se odnose na prisustvo negativnih emocija i njihovo potiskivanje $u$ socijalnim relacijama.

Ključne reči: A tip ponašanja, D tip ličnosti, sklonost ka psihosomatiskim ispoljavanjima

Received: 20. 02. 2019.

Revision received: 22. 04. 2019. Accepted for publication: 26. 05. 2019.
\end{abstract}

\footnotetext{
${ }^{3}$ Adresa autora: damjana.panic@filfak.ni.ac.rs
} 